\title{
HOW IS QUANTITATIVE EASING DIFFERENT FROM OPERATION TWIST? A LOOK AT THE ANNOUNCEMENT EFFECT ON BROAD STOCK INDEX AND GOLD PRICE
}

\author{
Jong-Hwan Yi, California State University Los Angeles \\ James Refalo, California State University Los Angeles
}

dx.doi.org/10.18374/JIFE-13-4.8

\begin{abstract}
We examine the announcement effect of recent U.S. monetary policy on S\&P 500 index and the price of gold's futures contract. Consistent with conventional expectations, we find that the stock market reacted positively to quantitative easing measures that resulted in an expansion of the FED's balance sheet. Likewise, the response of the gold futures contract price was consistent with a market perception that these operations were inflationary. However, we find the S\&P index and the gold futures price reacted negatively to Operation Twist, which was another liquidity enhancing operation that did not result in money creation.
\end{abstract}

Keywords: Quantitative Easing, Monetary Policy, S\&P 500, Equities, Stock Indices, Gold Futures. 